\title{
Korelasi Nilai UN, IP Tahun Pertama Terhadap Masa Studi Dengan Backpropagation
}

\section{Correlation of Final Examination, GPA for Study Period With Backpropagation}

\author{
Mariana Windarti ${ }^{1}$, Istri Sulistyowati ${ }^{2}$ \\ ${ }^{1}$ Program Studi Manajemen Informatika, Fakultas Ilmu Komputer, Universitas Widya Dharma Klaten \\ ${ }^{2}$ Program Studi Teknik Informatika, Fakultas Ilmu Komputer, Universitas Widya Dharma Klaten \\ e-mail: ${ }^{1}$ mariana@unwidha.ac.id, ${ }^{2}$ istri@unwidha.ac.id
}

\begin{abstract}
Abstrak
Pada pendidikan tinggi prestasi akademik dapat dilihat dari nilai Indeks Prestasi Kumulatif (IPK) dan masa studi sedangkan pada pendidikan sekolah menengah ditunjukkan dengan nilai Ujian Akhir Nasional (UAN) atau Ujian Nasional (UN). Hubungan beberapa variabel seperti nilai UAN, IP dan masa studi dapat dinyatakan dengan mengukur tingkat korelasi menggunakan sejumlah data mahasiswa. Data yang digunakan dalam penelitian ini adalah data alumni program studi Teknik Informatika Universitas Widya Dharma Klaten dengan tahun lulus 2013-2017. Tujuan penelitian untuk mengukur tingkat korelasi antara atribut nilai UAN dan IP tahun pertama terhadap masa studi mahasiswa menggunakan metode jaringan syaraf tiruan backpropagation yang diterapkan pada perangkat lunak Matlab r2013a. Pada proses pelatihan jaringan, penelitian ini menghasilkan nilai MSE (Mean Square Error) sebesar 0.0051721 dan koefisien korelasi $(R=0.56563)$. Sedang pada proses pengujian nilai $M S E=0.025073$ dan $R=-0.031142$. Selain itu hasil ini membuktikan bahwa nilai UAN dan IPK tahun pertama memiliki korelasi negatif terhadap masa studi mahasiswa.
\end{abstract}

Kata kunci-korelasi , data mining, masa studi, backpropagation

\begin{abstract}
In higher education academic achievement can be seen from the Grade Point Average (GPA) and study period while in secondary school education is indicated by the value of the National Final Examination (UAN) or National Examination (UN). The relationship of several variables such as UAN, IP and study period can be expressed by measuring the level of correlation using a number of data. The data used in this study is alumni data from the Informatics Engineering of the University of Widya Dharma Klaten with the graduating year from 2013 untill 2017. The research objective was to measure the level of correlation between UAN value attributes and the first year IP on the study period using the backpropagation method in neural network applied to the Matlab r2013a. In the process of network training, this study produced the MSE (Mean Square Error) value of 0.0051721 and the correlation coefficient $(R=0.56563)$. While in the testing process the value of MSE $=0.025073$ and $R=-$ 0.031142 . In addition, these results prove that the UAN and first-year GPA values have a negative correlation with the student's study period.
\end{abstract}

Keywords - correlation, data mining, study period, backpropagation 


\section{PENDAHULUAN}

Kualitas perguruan tinggi ditunjukkan dengan prestasi akademik yang dicapai oleh mahasiswa. Prestasi akademik pada dunia pendidikan merupakan salah satu tolak ukur dari keberhasilan proses belajar mengajar. Menurut Wikipedia Indeks Prestasi adalah salah satu alat ukur prestasi di bidang akademik. Meskipun bernama "indeks", IP sebenarnya bukanlah indeks dalam pengertian sebenarnya, melainkan semacam rerata terboboti. Masa studi merupakan lama studi terjadwal yang harus ditempuh oleh mahasiswa sesuai dengan rentang waktu yang dipersyaratkan. Pada jenjang sekolah menengah prestasi akademik ditunjukkan dengan nilai UAN (Ujian Akhir Nasional).

Beberapa penelitian telah dilakukan untuk menganalisa tentang kinerja mahasiswa yaitu variabel yang mempengaruhi kinerja mahasiswa baik IPK, lama studi maupun faktor lain seperti faktor internal dan eksternal. Penelitian ini bertujuan untuk menganalisa korelasi antara atribut yang berkaitan dengan kinerja mahasiswa seperti nilai UAN yang mempengaruhi IPK yang diperoleh selama menempuh studi atau IPK yang mempengaruhi masa studi, dan lain-lain. Atribut untuk memprediksi kelulusan mahasiswa dapat dilakukan berdasarkan usia, jenis kelamin, Indeks Prestasi semester 1 (satu) sampai semester 4 [1]. Implementasi lain yang diterapkan oleh Jaringan Saraf Tiruan (JST) salah satunya untuk melakukan prediksi jumlah pasien rawat inap. Tujuan penelitian ini adalah untuk memprediksi keterjumlah kematian dengan hanya menganalisa data yang tersedia, sehingga akan diketahui prediksi jumlah pasien rawat inap [2]. Penerapan JST untuk prediksi juga dilakukan untuk memprediksi jumlah reservasi kamar hotel dengan metode backpropagation. Penelitian ini menghasilkan prediksi yang tepat dan akurat, sehingga hasilnya dapat menjadi bahan pertimbangan keputusan bagi pihak manajemen hotel. Hasil prediksi yang diperoleh mempunyai tingkat akurasi $99.99 \%$ dan tingkat kesalahan $0.01 \%$ [3].

Penelitian lain yang dilakukan sebelumnya yaitu Nuraeni, 2009 mengenai penerapan Jaringan Saraf Tiruan untuk mengukur tingkat korelasi antara NEM dan IPK kelulusan mahasiswa menggunakan metode Backpropagation menyimpulkan bahwa NEM tidak dapat dijadikan acuan mutlak dalam sistem seleksi Penerimaan Mahasiswa Baru. Metode backpropagation memiliki tingkat keberhasilan sebesar $64 \%$ dalam memetakan hubungan antara NEM dan IPK lulusan [4]. Penelitian serupa dengan menerapkan metode backpropagation untuk mengetahui korelasi antara nilai rata-rata rapor dan IPK akhir mahasiswa. Penelitian ini menunjukkan bahwa nilai rata-rata rapor siswa tidak cukup menjamin untuk mendapatkan IPK akhir yang di perguruan tinggi. Sehingga tidak ada korelasi antara nilai rata-rata rapor dan IPK akhir Mahasiswa [5]. Penelitian tahun 2015 dilakukan untuk menganalisa hubungan Indeks Prestasi Kumulatif (IPK) dengan Nilai Ujian Akhir Nasional (UAN). Analisa dilakukan terhadap mahasiswa Jurusan Matematika, FMIPA Unsyiah, Aceh. Pengujian korelasi menunjukkan bahwa IPK berkorelasi positif dengan setiap nilai mata pelajaran UN. Faktor yang paling berpengaruh terhadap IPK mahasiswa FMIPA Unsyiah adalah nilai Bahasa Indonesia dan Asal Kabupaten [6].

Untuk dapat mengukur tingkat korelasi dan menganalisa hubungan antara variabel tersebut dapat menggunakan sejumlah data yang tersimpan dalam basis data. Data yang digunakan adalah data alumni S1 Teknik Informatika Universitas Widya Dharma (UNWIDHA) Klaten dengan tahun lulus 2013-2017. Atribut yang digunakan antara lain nilai UAN, Indeks Prestasi (IP) tahun pertama yaitu IP Semester 1 dan 2 dan masa studi mahasiswa. Untuk mengukur tingkat korelasi dengan metode backpropagation menggunakan perangkat lunak MATLAB R2013a. Proses untuk mendapatkan informasi yang berguna dari sejumlah data yang besar disebut dengan data mining atau penambangan data [7]. Terdapat banyak metode didalam penambangan data, salah satunya adalah Jaringan Syaraf Tiruan (JST) atau Neural Network. JST merupakan sistem pemroses informasi yang memiliki karakteristik mirip dengan jaringan syaraf biologi. Ada berbagai metode atau model jaringan berdasarkan strategi pelatihan yaitu 
pelatihan dengan supervisi terdiri dari model Hebbian, Perceptron, Adaline, Backpropagation, dll. Dalam penelitian ini penulis menggunakan metode backpropagation. Menurut penelitian tahun 2017 metode backpropagation lebih baik dibandingkan metode Adaline, sehingga penulis lebih memilih backpropagation dalam penelitian ini. Metode backpropagation dan adaline digunakan untuk meramal atau memperkirakan seberapa besar curah hujan yang akan datang. Hasil peramalan dengan tingkat kesalahan lebih kecil dari kedua metode tersebut yang menunjukkan metode yang baik. Berdasarkan pengujian yang telah dilakukan pada iterasi 1000 dihasilkan Root Mean Square Error (RMSE) pada metode Backpropagation sebesar 0.0435, sedangkan Adaline sebesar 0.0674. Semakin kecil nilai RMSE maka akan semakin baik metode tersebut. Berdasarkan perbandingan nilai RMSE metode Backpropagation lebih baik dibandingkan dengan metode Adaline[8].

Penambangan data yang diimplementasikan di bidang pendidikan dikenal dengan istilah Educational Data Mining (EDM). Penelitian terkait EDM dilakukan tahun 2015 menghasilkan analisa bahwa IPK merupakan atribut penting dalam mengukur kinerja mahasiswa, karena IPK merupakan atribut yang memiliki nilai yang nyata (tangible value). Hasil penelitian tersebut diperoleh bahwa metode Neural Network memiliki tingkat akurasi tertinggi sebesar 98\%, kemudian Decision Tree sebesar 91\%, Support Vector Machine \& KNN (K-Nearest Neighbors) memiliki akurasi yang sama $83 \%$ dan akurasi terendah dimiliki oleh Naive Bayes sebesar $76 \%$ [9].

Peneliti bermaksud untuk melakukan analisa dengan mengukur tingkat korelasi nilai UAN dan IP tahun pertama yaitu IP semester 1 dan semester 2 terhadap masa studi mahasiswa menggunakan jaringan syaraf tiruan backpropagation. Kemudian menganalisa apakah atribut tersebut memiliki korelasi positif atau tidak terhadap masa studi yang ditempuh mahasiswa. Dengan menganalisa tingkat korelasi antara variabel tersebut diharapkan pihak perguruan tinggi dapat memperhatikan faktor-faktor yang mempengaruhi lama studi mahasiswa, apakah faktor tersebut hanya dipengaruhi oleh nilai UAN atau IP tahun pertama saja, atau terdapat faktor lain yang mempengaruhi masa studi mahasiswa.

\section{METODE PENELITIAN}

\subsection{Pengumpulan Data}

Pengumpulan data mentah dilakukan secara langsung yaitu diperoleh dari bagian akademik Fakultas Ilmu Komputer UNWIDHA. Data yang digunakan dengan mengambil variabel input berupa nilai UAN yang terdiri dari mata pelajaran matematika, bahasa Indonesia dan bahasa inggris, kemudian nilai IP Tahun Pertama yaitu IP semester 1 dan 2. Sedangkan variabel output adalah lama studi yang berasal dari tahun masuk dan tanggal kelulusan. Data diambil dari mahasiswa yang telah selesai menempuh pendidikan S1 Teknik Informatika dengan tahun lulus 2013-2017 yaitu sebanyak 200 record data. Data pelatihan menggunakan 150 record, sedangkan pengujian sebanyak 50 record. Seluruh data tersebut sudah mengalami tahap preprocessing data atau normalisasi sehingga sudah tidak terdapat lagi data yang hilang atau kosong dan data yang variabelnya tidak digunakan akan dihilangkan.

Sampel data yang digunakan dapat dilihat pada tabel 1 dibawah ini. Pada tabel tersebut dapat dilihat variabel input adalah $\mathrm{x} 1, \mathrm{x} 2, \mathrm{x} 3, \mathrm{x} 4$ dan $\mathrm{x} 5$ sedangkan variabel output atau target adalah y yang menyatakan masa studi. Nilai pada tabel 1 tersebut adalah data sebelum dilakukan proses normalisasi. Nilai pada variabel y untuk record atau data pertama tertulis 4.5 maksudnya masa studi yang ditempuh mahasiswa adalah 4 tahun 5 bulan, begitu juga untuk data pada record berikutnya. 
Tabel 4.1. Sampel Data Pelatihan \& Pengujian

\begin{tabular}{ccccccc}
\hline No & $\mathbf{x 1}$ & $\mathbf{x 2}$ & $\mathbf{x 3}$ & $\mathbf{x 4}$ & $\mathbf{x 5}$ & $\mathbf{y}$ \\
\hline 1 & 9 & 5.6 & 6 & 3.61 & 3.36 & 4.5 \\
\hline 2 & 8 & 7 & 5 & 3.09 & 3 & 4.6 \\
\hline 3 & 8 & 6.6 & 7 & 2.78 & 3.05 & 5.1 \\
\hline 4 & 7.5 & 7.67 & 6.67 & 3.04 & 3.13 & 4.6 \\
\hline 5 & 7 & 5 & 5 & 3 & 2.83 & 4.5 \\
\hline 6 & 7.4 & 7 & 8 & 3.16 & 3.08 & 4.5 \\
\hline 7 & 8 & 8.2 & 8.33 & 3.18 & 2.74 & 4.7 \\
\hline 8 & 6.8 & 7 & 6.67 & 3 & 2.91 & 3.8 \\
\hline 9 & 9 & 4.6 & 6.75 & 3 & 2.82 & 3.8 \\
\hline 10 & 5.8 & 8.4 & 5.75 & 3.35 & 2.82 & 4.6 \\
\hline 11 & 8.2 & 7.4 & 8.67 & 3 & 2.73 & 4.6 \\
\hline 12 & 9 & 5 & 9.25 & 3.09 & 2.82 & 4.4 \\
\hline 13 & 8.4 & 8.4 & 7.25 & 2.91 & 2.64 & 4.5 \\
\hline 14 & 8 & 4.8 & 7.25 & 3.43 & 3.09 & 4.4 \\
\hline 15 & 6.6 & 7 & 6.75 & 3.61 & 3 & 4.5 \\
\hline 16 & 6.8 & 4.4 & 5.75 & 3.35 & 3 & 3.8 \\
\hline 17 & 8.8 & 5.6 & 7 & 3.35 & 3 & 4.3 \\
\hline 18 & 7.67 & 6.83 & 8.67 & 3.43 & 3.2 & 4.4 \\
\hline 19 & 6.8 & 7.6 & 7.33 & 3.26 & 3 & 4.5 \\
\hline 20 & 6 & 6 & 5 & 3.3 & 3.05 & 4.4 \\
\hline 21 & 7.8 & 8.6 & 8 & 3.43 & 3.36 & 4.4 \\
\hline 22 & 6 & 6.4 & 4.75 & 3.26 & 3 & 4.4 \\
\hline 23 & 6 & 4 & 4 & 3.48 & 2.8 & 4.1 \\
\hline 24 & 7 & 8.8 & 6.33 & 3.17 & 2.73 & 4.5 \\
\hline 25 & 4.6 & 5.6 & 7 & 3.26 & 2.36 & 4.8 \\
\hline & & & & & &
\end{tabular}

\section{Keterangan :}

\begin{tabular}{lc}
\hline Nilai Bahasa Indonesia & $\mathrm{X} 1$ \\
\hline Nilai Bahasa Inggris & $\mathrm{X} 2$ \\
\hline Nilai Matematika & $\mathrm{X} 3$ \\
\hline Nilai IP semester 1 & $\mathrm{X} 4$ \\
\hline Nilai IP semester 2 & $\mathrm{X} 5$ \\
\hline Masa Studi & $\mathrm{Y}$ \\
\hline
\end{tabular}

\subsection{Tahapan Penelitian}

Ada beberapa tahapan yang dilakukan dalam penelitian ini antara lain:

a. Studi Pustaka, yaitu mengumpulkan data atau informasi yang bersumber dari internet, buku, jurnal, penelitian maupun referensi lainnya.

b. Pengumpulan data yang dilakukan secara langsung ke bagian akademik Fasilkom UNWIDHA.

c. Melakukan tahapan preprocessing dengan mereduksi data yang kosong atau yang memiliki nilai atribut tidak lengkap.

d. Implementasi metode backpropagation menggunakan MATLAB R2013a dengan mengukur tingkat korelasi.

e. Menganalisa hasil yang diperoleh melalui nilai koefisien korelasi apakah memiliki korelasi positif atau negatif. 


\subsection{Arsitektur Jaringan}

Metode Backpropagation terdiri dari beberapa layar yang muncul untuk mengatasi kelemahan JST yang hanya terdiri dari layar tunggal. JST dengan layar tunggal memiliki keterbatasan dalam pengenalan pola. Backpropagation melatih jaringan untuk mendapatkan keseimbangan antara kemampuan jaringan untuk mengenali pola yang digunakan selama pelatihan serta kemampuan jaringan untuk memberi respon yang benar terhadap pola masukan yang serupa [10].

Dalam proses pelatihan dan pengujian jaringan ini memiliki 3 lapisan yaitu satu lapisan masukan (input) yang terdiri atas 5 unit sel, satu lapisan tersembunyi sebanyak 10 unit sel dan satu lapisan keluaran yang berjumlah 1 unit sel sebagai target/output. Perancangan arsitektur jaringan yang digunakan untuk mengukur tingkat korelasi nilai UAN, IP tahun pertama terhadap masa studi dapat dilihat pada gambar 1 berikut ini.

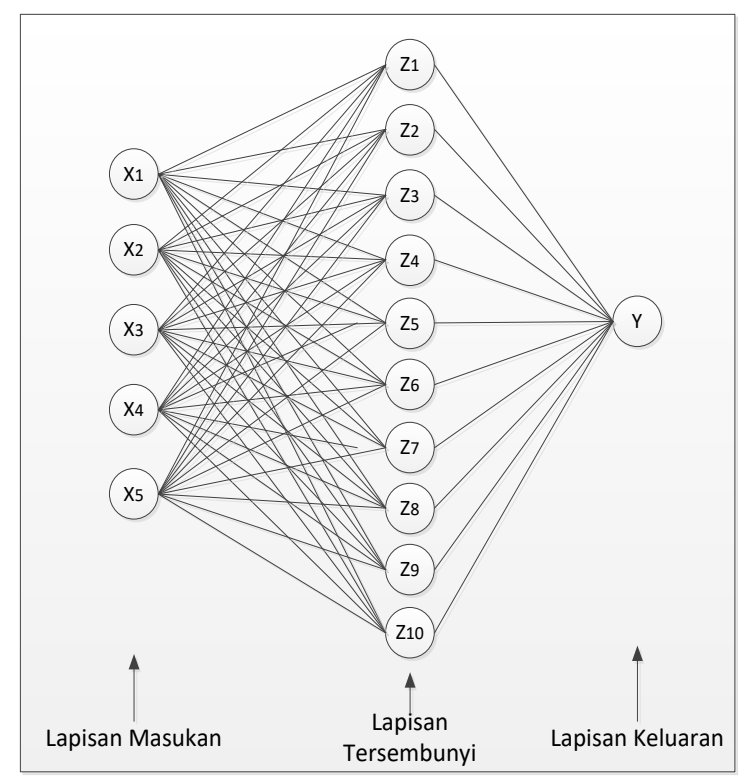

Gambar 1. Arsitektur Jaringan Pengukuran Tingkat Korelasi

\section{HASIL DAN PEMBAHASAN}

\subsection{Proses Normalisasi Data}

Didalam melakukan pelatihan dan pengujian jaringan backpropagation, data dinormalisasi terlebih dahulu. Tujuannya untuk mereduksi perhitungan komputasi yang terlalu besar. Hasil proses normalisasi data akan diperoleh nilai dalam range 0.1 s.d 0.9. Perintah yang digunakan untuk melakukan normalisasi pada Matlab dapat dilihat pada gambar 2 berikut ini. 
Mariana Windarti, Istri Sulistyowati

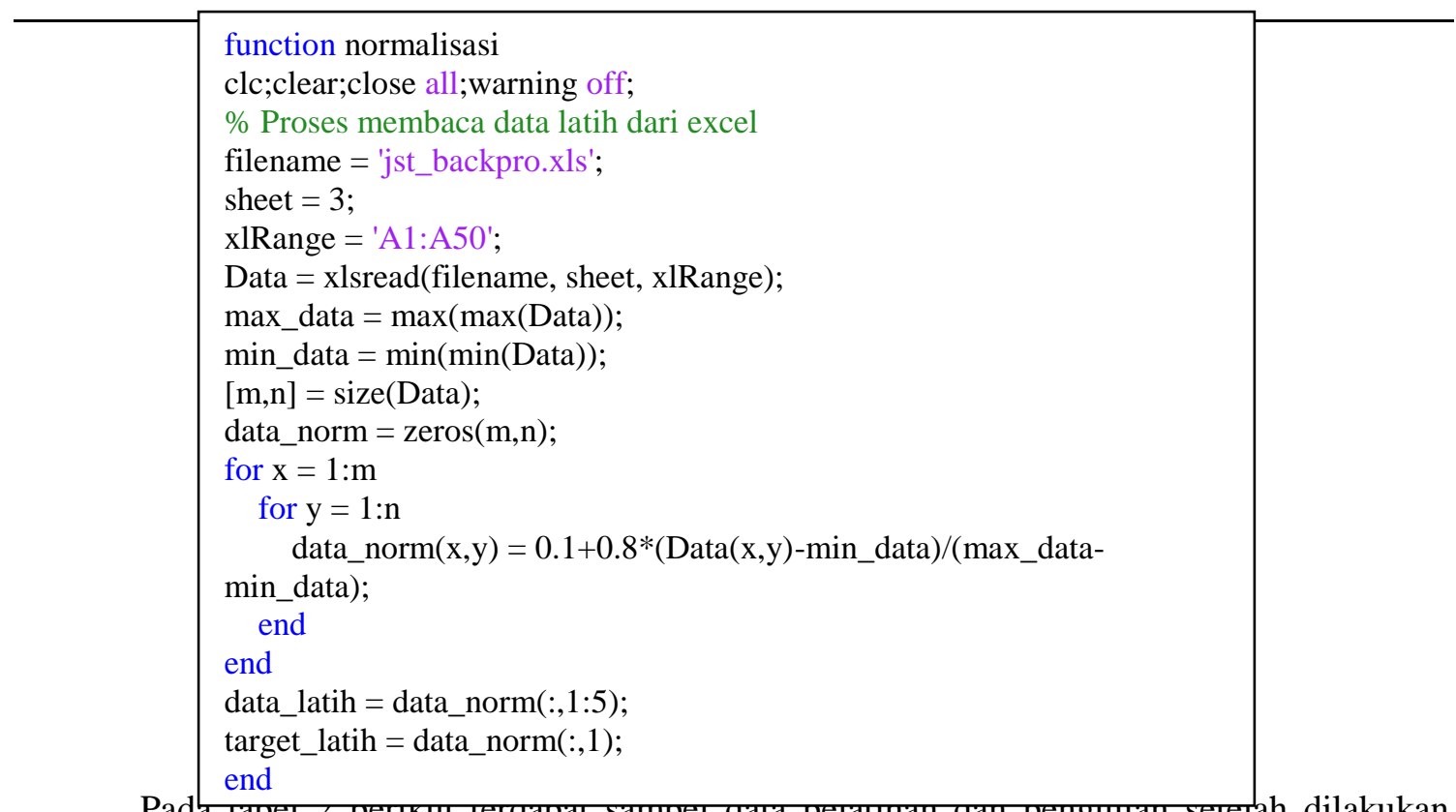
proses normalisasi yang berasal dari data mentah. Variabel input adalah $\mathrm{x} 1, \mathrm{x} 2, \mathrm{x} 3, \mathrm{x} 4$ dan $\mathrm{x} 5$ sedangkan variabel output atau target adalah y. Sedangkan untuk hasil normalisasi dapat dilihat pada tabel 2 dibawah ini.

Tabel 2. Hasil Normalisasi Sampel Data Pelatihan \& Pengujian

\begin{tabular}{ccccccc}
\hline No & $\mathbf{x 1}$ & $\mathbf{x 2}$ & $\mathbf{x 3}$ & $\mathbf{x 4}$ & $\mathbf{x 5}$ & $\mathbf{y}$ \\
\hline 1 & 0.809 & 0.498 & 0.534 & 0.316 & 0.293 & 0.355 \\
\hline 2 & 0.717 & 0.626 & 0.443 & 0.268 & 0.260 & 0.389 \\
\hline 3 & 0.717 & 0.589 & 0.626 & 0.240 & 0.265 & 0.389 \\
\hline 4 & 0.671 & 0.687 & 0.596 & 0.264 & 0.272 & 0.389 \\
\hline 5 & 0.626 & 0.443 & 0.443 & 0.260 & 0.244 & 0.338 \\
\hline 6 & 0.662 & 0.626 & 0.717 & 0.275 & 0.267 & 0.338 \\
\hline 7 & 0.717 & 0.735 & 0.747 & 0.276 & 0.236 & 0.372 \\
\hline 8 & 0.607 & 0.626 & 0.596 & 0.260 & 0.252 & 0.219 \\
\hline 9 & 0.809 & 0.406 & 0.603 & 0.260 & 0.244 & 0.219 \\
\hline 10 & 0.516 & 0.754 & 0.511 & 0.292 & 0.244 & 0.355 \\
\hline 11 & 0.735 & 0.662 & 0.778 & 0.260 & 0.235 & 0.355 \\
\hline 12 & 0.809 & 0.443 & 0.831 & 0.268 & 0.244 & 0.321 \\
\hline 13 & 0.754 & 0.754 & 0.649 & 0.252 & 0.227 & 0.338 \\
\hline 14 & 0.717 & 0.425 & 0.649 & 0.299 & 0.268 & 0.321 \\
\hline 15 & 0.589 & 0.626 & 0.603 & 0.316 & 0.260 & 0.338 \\
\hline 16 & 0.607 & 0.388 & 0.511 & 0.292 & 0.260 & 0.219 \\
\hline 17 & 0.790 & 0.498 & 0.626 & 0.292 & 0.260 & 0.304 \\
\hline 18 & 0.687 & 0.610 & 0.778 & 0.299 & 0.278 & 0.321 \\
\hline 19 & 0.607 & 0.681 & 0.656 & 0.284 & 0.260 & 0.338 \\
\hline 20 & 0.534 & 0.534 & 0.443 & 0.287 & 0.265 & 0.321 \\
\hline & & & & & &
\end{tabular}

3.2 Hasil

Pelatihan JST

Backpropagation 
Data pelatihan yang digunakan sebanyak 150 record data yang sudah mengalami tahap preprocessing data dan normalisasi. Pelatihan jaringan dengan Matlab ini menggunakan parameter epoch sebesar 50000, goal (error) atau batas error 0.001 , learning rate 0.1 dan menggunakan fungsi aktivasi sigmoid biner (logsig). Dari hasil pelatihan jaringan didapat nilai MSE (Mean Square Error) 0.0051721 dan koefisien korelasi (R) 0.56563. Dalam backpropagation, perhitungan unjuk kerja dilakukan berdasarkan kuadrat rata-rata kesalahan yaitu MSE (Mean Square Error). Grafik keluaran hasil pelatihan jaringan terhadap 150 record data dapat dilihat pada gambar 3 berikut ini. Sedangkan proses running neural network pada Matlab dapat dilihat pada gambar 4 dibawah ini.

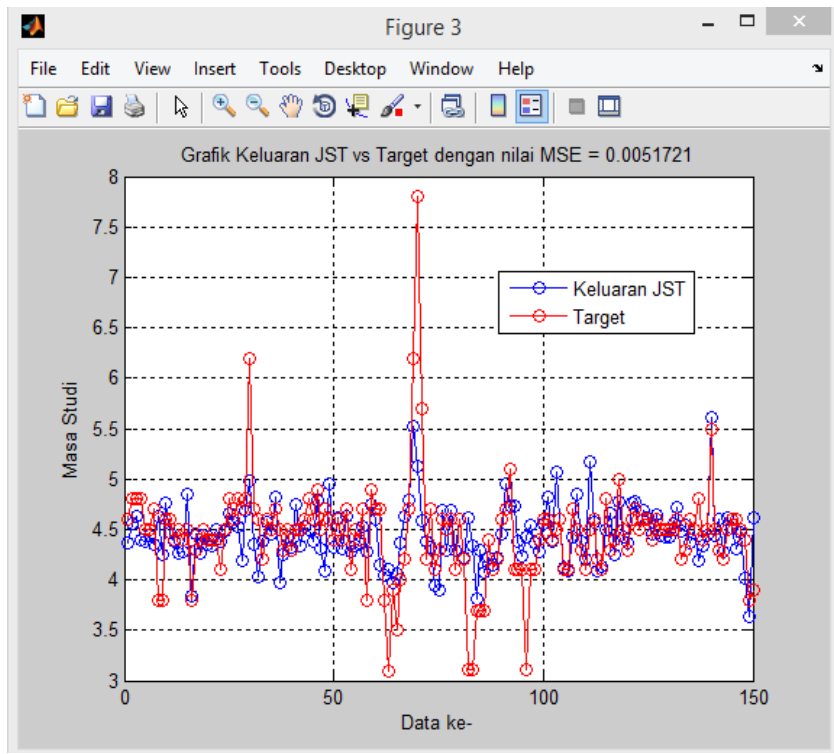

Gambar 3. Hasil Pelatihan JST Backpropagation

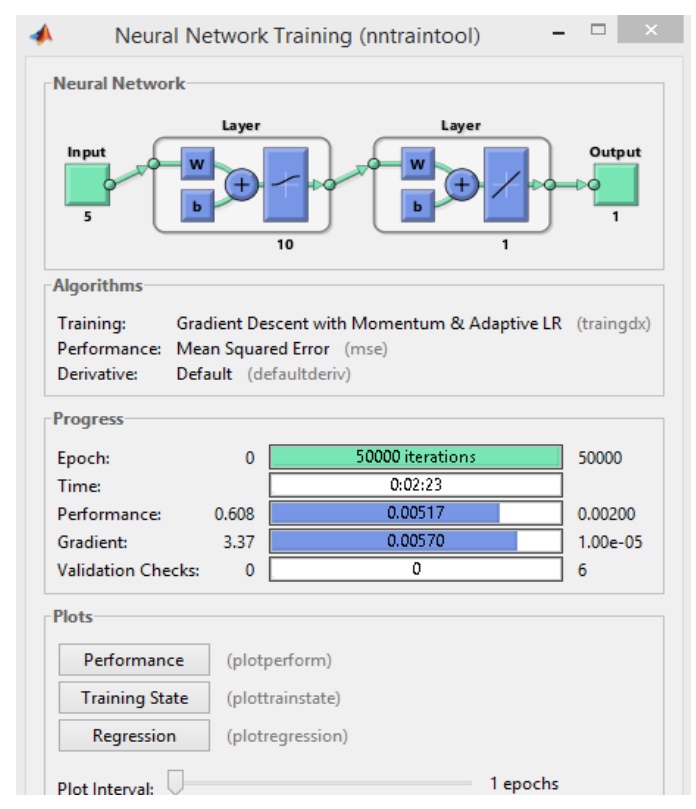

Gambar 4. Training JST Backpropagation pada Matlab 
Hasil pelatihan yang dinyatakan dalam nilai koefisien korelasi dikatakan cukup baik karena lebih dari separuh batas maksimal yaitu 0.5. Koefisien korelasi memiliki nilai maksimum sebesar 1 . Grafik yang menunjukkan koefisien korelasi $\mathrm{R}=0.56563$ pada proses pelatihan dapat dilihat pada gambar 5 berikut ini. Sedangkan untuk parameter epoch yang digunakan yaitu sebanyak 50000 dapat dilihat pada gambar 6.

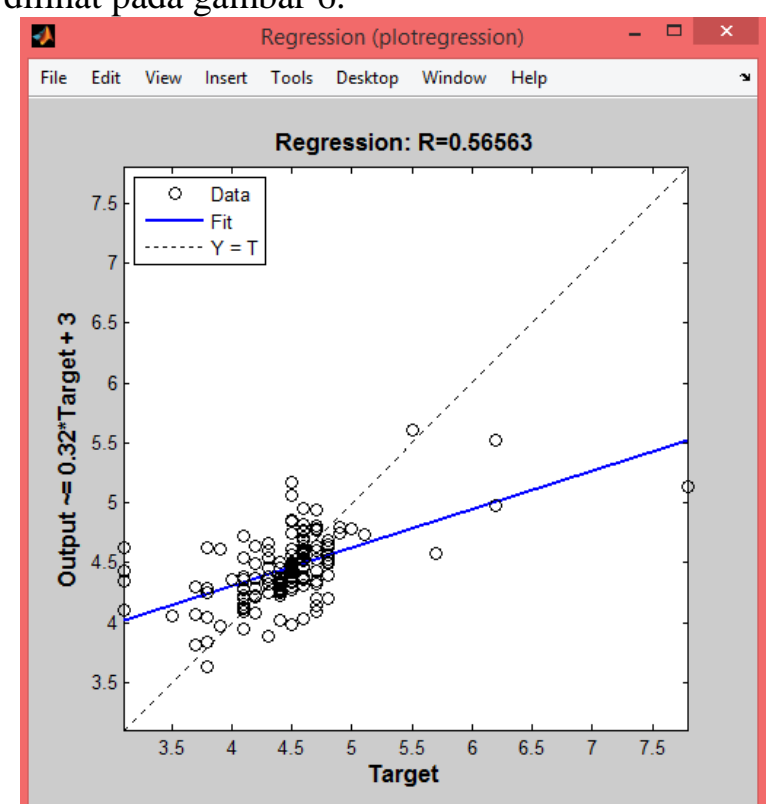

Gambar 5. Hasil Pelatihan dengan Korelasi $(\mathrm{R}=0.56563)$

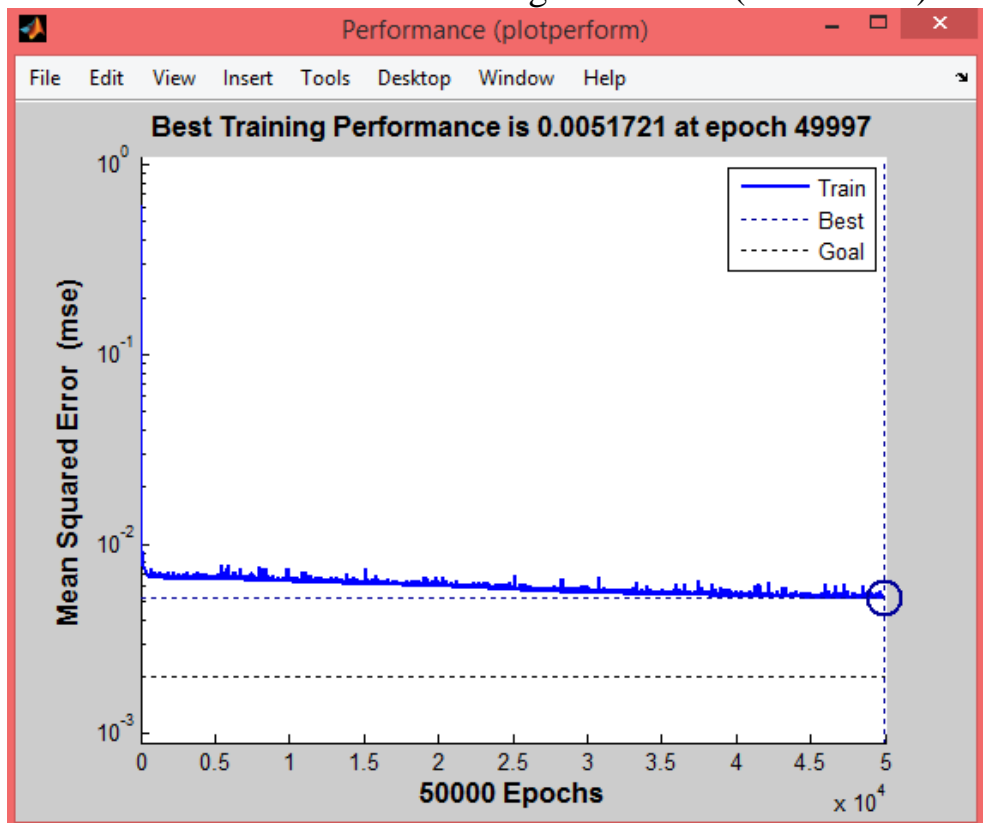

Gambar 6. Grafik Hasil Pelatihan dengan Parameter Epoch 50000

\subsection{Hasil Pengujian JST Backpropagation}

Data pengujian yang digunakan sebanyak 50 record data. Dari hasil pengujian jaringan didapat nilai MSE (Mean Square Error) sebesar 0.025073 dan koefisien korelasi -0.031142. 
Korelasi Nilai UN, IP Tahun Pertama Terhadap Masa Studi ...

Dari hasil pengujian ini varibel nilai UAN, IPK semester $1 \& 2$ terhadap masa studi memiliki korelasi negatif, maksudnya tidak ada korelasi antara nilai UAN dan IP tahun pertama terhadap masa studi. Untuk memperoleh korelasi positif dapat dilakukan dengan menambah variabel yang digunakan dan memperbanyak data pelatihan dan pengujian jaringan. Hasil pengujian dapat dilihat pada gambar 7 berikut ini, sedangkan hasil koefisien korelasi dalam bentuk grafik dapat dilihat pada gambar 8 berikut.

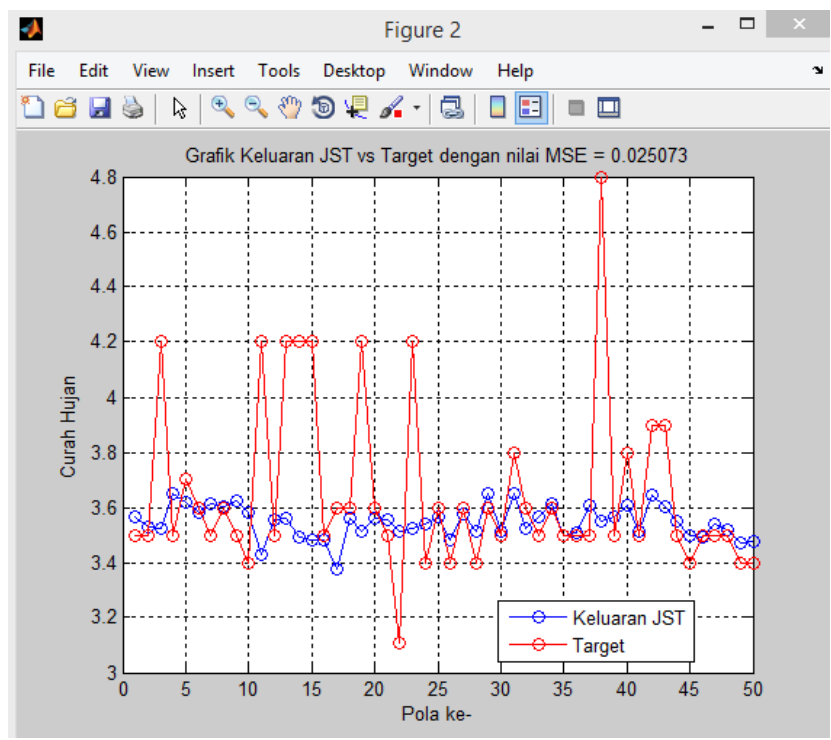

Gambar 6. Hasil Pengujian JST Backpropagation

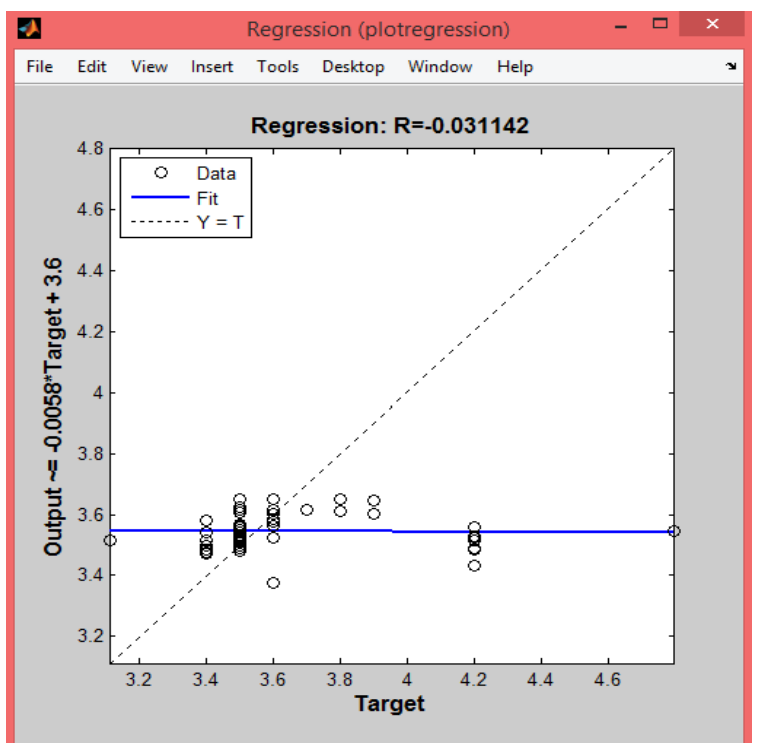

Gambar 7. Hasil Pengujian dengan Korelasi ( $\mathrm{R}=-0.031142$ )

\section{KESIMPULAN}

Kesimpulan yang diperoleh setelah melakukan penelitian ini antara lain data pelatihan yang digunakan sebanyak 150 record dan pengujian 50 record data. Penerapan JST 
Backpropagation dilakukan untuk mengukur tingkat korelasi nilai UAN, IP Semester 1 dan 2 terhadap masa studi mahasiswa ini diterapkan pada perangkat lunak MATLAB menggunakan parameter epoch 50000, learning rate 0.1, goal (error) 0.002, 1 lapisan tersembunyi (hidden layer) dengan jumlah neuron sebanyak 10 dan menggunakan fungsi sigmoid biner (logsig). Pada Proses Pelatihan jaringan menghasilkan nilai akurasi MSE 0.0051721 dan koefisien korelasi sebesar 0.56563 . Nilai korelasi berada pada rentang $0-1$ dan korelasi terbaik bernilai 1. Dalam proses pelatihan jaringan sudah menghasilkan kinerja yang cukup. Sedangkan pada proses pengujian pada 50 record data diperoleh kecocokan antara output jaringan dan target dengan koefisien korelasi (R) sebesar -0.031142 dan nilai MSE sebesar 0.025073. Jadi korelasi antara nilai UAN, IP Semester $1 \& 2$ terhadap masa studi mahasiswa memiliki korelasi negatif atau tidak memiliki korelasi, sehingga diperlukan variabel lain atau faktor lain yang mendukung masa studi mahasiswa, selain itu perlu menambah jumlah data baik untuk data pelatihan maupun data pengujian.

\section{SARAN}

Saran yang dapat dilakukan untuk dilakukan penelitian selanjutnya antara lain:

a. Nilai MSE yang diperoleh sedikit lebih tiggi dari separuh batas maksimal yaitu 0.5 (MSE = 0.56563) sehingga belum menghasilkan kinerja yang maksimal.

b. Dibutuhan faktor-faktor lain yang mendukung masa studi mahasiswa, tidak hanya faktor nilai UAN dan IP Semester $1 \& 2$ saja. Selain itu juga perlu memperbanyak data yang digunakan dalam proses pelatihan dan pengujian.

c. Proses pelatihan dan pengujian dapat dilakukan kedalam beberapa model atau bentuk dengan mengubah nilai parameter yang digunakan seperti jumlah parameter epoch, nilai laju belajar (learning rate), batas error, fungsi aktivasi, jumlah lapisan pada hidden layer dan lain-lain.

\section{UCAPAN TERIMA KASIH}

Penulis mengucapkan terima kasih kepada Program Studi Teknik Informatika, Fakultas Ilmu Komputer UNWIDHA Klaten. Kemudian tidak lupa juga kepada Lembaga Penelitian dan Pengabdian Kepada Masyarakat (LPPM) Unwidha Klaten yang telah mendanai penelitian ini sehingga penelitian ini dapat selesai dan berjalan dengan baik.

\section{DAFTAR PUSTAKA}

[1] A. Romadhona, Suprapedi, and H. Himawan, "Prediksi Kelulusan Mahasiswa Tepat waktu Berdasarkan Usia, Jenis Kelamin dan Indeks Prestasi Menggunakan Algoritma Decision Tree," J. Teknol. Inf., vol. 13, no. 1, pp. 69-83, 2017.

[2] F. R. Diani Br. Simangunsong and S. D. Nasution, "Aplikasi Jaringan Saraf Tiruan Untuk Memprediksi Metode Back Propagation (Studi Kasus: RSU. TERE MARGARETH)," J. Ris. Komput., vol. 2, no. 6, pp. 43-47, 2015.

[3] M. Yanto, S. Defit, and G. W. Nurcahyo, "Memprediksi Jumlah Reservasi Kamar Hotel dengan Metode Backpropagation ( Studi Kasus Hotel Grand Zuri Padang )," J. KomTekInfo Fak. Ilmu Komput., vol. 2, no. 1, 2015.

[4] Y. Nuraeni, "Penerapan Jaringan Syaraf Tiruan untuk Mengukur Tingkat Korelasi Antara NEM dengan IPK Kelulusan Mahasiswa," J. TELKOMNIKA (Telecommunication Comput. Electron. Control., vol. 7, no. 3, pp. 195-200, 2009. 
Korelasi Nilai UN, IP Tahun Pertama Terhadap Masa Studi ...

[5] D. Utami, "Penerapan Jaringan Saraf Tiruan untuk mengetahui Korelasi antara Nilai Rata-rata Rapor dan IPK Akhir Mahasiswa dengan Menggunakan Metode Backpropagation," Skripsi Jurusan Teknik Informatika UNIVERSITAS ISLAM NEGERI SULTAN SYARIF KASIM RIAU, 2016.

[6] R. Ferdhiana, I. Julita, A. Rusyana, and N. Salwa, "Hubungan Indeks Prestasi Kumulatif ( IPK ) dengan Nilai Ujian Akhir Nasional ( UAN ): Studi Kasus di FMIPA Unsyiah,” vol. 15, no. 1, pp. 17-23, 2015.

[7] H. Jiawei and M. Kamber, Data mining: concepts and techniques. 2001.

[8] I. P. Sutawinaya, I. N. Gede Arya Astawa, and N. K. D. Hariyanti, "Perbandingan Metode Jaringan Saraf Tiruan pada Peramalan Curah Hujan," J. Log., vol. 17, no. 2, pp. 92-97, 2017.

[9] A. Mohamed, W. Husain, and A. Rashid, "A Review on Predicting Student' s Performance using Data Mining Techniques," Procedia - Procedia Comput. Sci., vol. 72, pp. 414-422, 2015.

[10] J. Jek Siang, Jaringan Syaraf Tiruan dan Pemrogramannya Menggunakan Matlab. Yogyakarta: Penerbit Andi, 2005. 